\title{
ESSAY
}

\section{ADIMINISTRATIVE FAILURE AND LOCAL DEMOCRACY: THE POLITICS OF DESHANEY}

\author{
JACK M. BEERMANN*
}

\section{INTRODUCTION}

This Essay is an effort to construct a normative basis for a constitutional theory to resist the Supreme Court's recent decision in DeShaney v. Winnebago County Department of Social Services. 1 In DeShaney, the Court decided that a local social service worker's failure to prevent child abuse did not violate the due process clause of the fourteenth amendment even though the social worker "had reason to believe" the abuse was occurring. ${ }^{2}$ Chief Justice Rehnquist's opinion for the Court leld that government inaction cannot violate due process unless the state lias custody of the victim, ${ }^{3}$ thus settling a controversial constitutional issue. This decision sliould be resisted because it tends to keep power from the powerless and preserves pohtical power in the liands of the few.

The glaring failures of the DeShaney opinion invite attack. Formalistic and unambitious in its examination of history, the opinion reaches out to decide the broadest constitutional issue presented. ${ }^{4}$ Most seriously, on the level of judicial craftsmanship, the opinion fails to engage in

* Professor of Law, Boston University School of Law. B.A., 1980, University of WisconsinMadison; J.D., 1983, University of Chicago.

I benefited from the generosity of many people who took the time to help nee with this projectamong them Kate Bartlett, Barbara Beermann, Eric Blumenson, Michael Collins, Richard Cudahy, Clay Gillette, Fred Lawrence, Chip Lupu, Bob Seidman, Ken Simons, Joe Singer, and Avi Soifer. Valuable research assistance was provided by Manal Corwin and Gloria LaPlante. A summer research grant front the Boston University School of Law provided financial support.

1. 489 U.S. 189 (1989).

2. Id. at 191.

3. The Court acknowledged that the state owres affirmative duties to people in state custody and suggested that it also might owe affirmative duties to cone to the aid of children placed by the state in foster care or others whose plight was caused or aggravated by state action. See id. at 198. 201, 198 n.5, 200 n.8, 201 n.9.

4. The Court declined to reach the non-constitutional issues of whether the defendants were immune and whether the standard for county liability was niet; it also declined to reach the constitutional issue of whether the state officials had the state of mind necessary to support a due process claim. See id. at 202 n.10. 
an in-depth discussion of the controversial coustitutional ${ }^{5}$ and ethical issues. ${ }^{6}$ But resolved to resist the temptation of attacking the easy targets, I focus instead on substantive objections to the theory that underhes DeShaney.

The ethical problems of the decision correspond to issues concerning the origins of and reinedies for administrative failure. The increasing role of administrators in our society has led to escalating levels of agency failure. Further, increased dependence on agency action increases the consequences of agency failure and thus makes judicial review all the inore unportant. If agency actions are to remain consistent with normative views that inform both the fourteenth amendment and the civil rights statutes, the federal judiciary should intervene when local administrative failure results in injury.

DeShaney involved a helpless child injured both by his father, the person to whoin society entrusted him for care and protection, and a social worker who exhibited incompetence and indifference to the child's welfare. This sort of situation presents a particularly strong example of the need for judicial intervention-it calls out for a new doctrinal picture of state and local government responsibility to protect individuals like Joshua DeShaney from private violence. But iny purpose is not to provide a definitive legal argument. Rather, I want to raise the possibility that the distinction between action and inaction, upon which the Court rehed, does not settle the issue. Instead, I beheve that a solution to the problem depends on a thorough understanding of the morality of governinent inaction and the role of government institutions in our society.

The developinent of a coherent normative structure to analyze problems like administrative failure is hampered by the Court's unwillingness to focus on systematic questions regardmg coinpensation for state-inflicted injuries. ${ }^{7}$ A central theine in the Court's recent due pro-

5. In disposing of the claim that the state's failure to prevent the child abuse violated substantive due process, the Court failed to analyze the issue under traditional substantive due process doctrine regarding the outrageousness, reasonableness, or acceptability to society of the challenged conduct. The Court avoided the question of the propriety of the state conduct by categorizing it as inaction and holding that inaction in this context could not violate the due process clause. See id. at 194-203. It is impossible to be more precise about this. The Court's opinion does not specify whether its reasoning entails a finding of no deprivation or a finding of no due process problem with a deprivation. See id.

6. Two issues that deserved serious attention were the extent of government's responsibility to care for helpless inembers of society, and the morality of government standing by while one member of society does violence to another. The Court avoided consideration of these central issues.

7. As I have argued elsewhere, in holding that state official torts do not violate the Coustitution, the Court fails to investigate the treatment by the state of its tort victims generally. "Government official torts would not look trivial or unimportant if the Court focused on the state's refusal to compensate rather than on the official's tortious conduct." Jack Beermann, Government Official 
cess jurisprudence is that state law-based tort actions should not be converted into due process violations inerely because state officials committed the tort. ${ }^{8}$ The Court adheres rigidly to this theine and appears uninterested in the question of whether coinpensation is available froin state officials for conduct that would generate hability for non-governmental defendants. ${ }^{9}$ Plaintiffs will continue to bring claims like the one in DeShaney to federal court to avoid state immunities or limits on tort recovery, and the Court should decide whether the immunities and limits imposed by the state are constitutional.

In developing this normative position I proceed as follows. First, I describe the DeShaney inajority's reasoning and einploy estabhished due process doctrine to provide another view of the constitutional propriety of state inaction. Second, I create an institutional context to explain why the Court's view that state inaction does not violate due process is both inconsistent with the responsibility that government bears for the welfare of citizens and outdated given the extensive role that administrative agencies play in our society. In situations such as DeShaney, government has a duty to protect weak ineinbers of society regardless of prior governinental actions. Further, the DeShaney context, in which government took an active role, gives rise to an even stronger argument for governinent responsibility. Building on this foundation, I base my argument for aggressive federal judicial intervention to inoritor and prevent state administrative failure on two grounds: (1) the responsibility of federal courts to protect citizens against state officials; and (2) the consequences for local deinocracy that result from unrestrained state administrative failure. From a local delnocracy standpoint, judicial intervention will kecp responsibility for administrative action within the confines of the local pohtical community, inaking local government inore accountable for administrative failure and thus inore deinocratic.

\section{THE NORMS OF DESHANEY}

DeShaney symbolizes the breakdown of institutions. The first institution that failed to function properly was a family. In 1980, custody of one-year-old Joshua DeShaney was awarded to his father, Randy

Torts and the Takings Clause: Federalism and State Sovereign Immunity, 68 B.U.L. REV. 277, 32324 (1988) [hereinafter Beermann, Official Torts].

8. See, e.g., Parratt v. Taylor, 451 U.S. 527 (1981) (no due process violation when random and unauthorized act of state official leads to deprivation of property and state provides adequate postdeprivation remedy); Daniels v. Williams, 474 U.S. 327, 328 (1986) ("[T] he Due Process Clause is simply not implicated by a negligent act of an official."). But cf. Zinermon v. Burch, $110 \mathrm{~S}$. Ct. 975 (1990) (Parratt does not apply if clain is for violation of substantive due process violation or if officials could have provided hearing to prevent foreseeable harms).

9. See DeShaney, 489 U.S. at 202-03; Beermann, Official Torts, supra note 7, at 323-24. 
DeShaney, by a Wyoming court as part of his parents' divorce. Randy moved to Wisconsin after the divorce, taking Joshua with him; by 1982 Randy had begun a pattern of violent child abuse that ended in 1984 with Joshua "suffer[ing] brain damage so severe that he is expected to spend the rest of his life confined to an institution for the profoundly retarded."10 Apparently no family members came to Joshua's aid: Joshua's mother surfaced only to initiate the section 1983 case that eventually made its way to the Supreme Court; the only other "family" person mentioned is Randy's girlfriend, whom social workers encouraged to move out of Randy's house as part of a program to prevent the abuse to Joshua. ${ }^{11}$

The Winnebago County Department of Social Services (the Department) was the next institution to break down. ${ }^{12}$ From the Supreme Court's opinion, we learn only a few details of the inistakes made by the Department and its social workers. After Joshua was treated at a hospital for suspicious injuries, the Department quickly obtained an order that granted the hospital temporary custody of Joshua, but three days later an ad hoc "Child Protection Team" decided that the evidence was not sufficient to keep Joshua from his father. The Team did, however, initiate a process through which Randy DeShaney agreed with the Department that Marie, Randy's girlfriend, would move out of the house and that Joshua would be sent to a Head Start school program. ${ }^{13}$

Marie never moved out, Joshua never went to the school, and less than two months after the agreement, Joshua went back to the hospital for treatment of suspicious injuries. Over the next few months, social workers who visited the DeShaney household noticed several injuries that indieated child abuse, and at least once the hospital informed the Department that it had treated Joshua for injuries arising from what the hospital officials thought was child abuse. Further, on several visits to the DeShaney home, social workers were told that Joshua was either

10. DeShaney, 489 U.S. at 193.

11. The court of appeals opinion provides a few more details: Randy DeShaney married and quickly divorced "a woman" on his arrival in Wisconsin; that woman's lawyer told police in 1982 that Randy had hit Joshua. See DeShaney v. Winnebago County Dep't of Social Servs., 812 F.2d 298, 299 (7th Cir. 1987). We also learn from the court of appeals that Randy's girlfriend was named Marie, that she brought Joshua to the hospital for treatment at least once, and that social workers wanted Marie out of the house because they suspected (due to accusations by Randy DeShaney) that she also was abusing Joshua. See id. at 299-300.

12. The DeShaney situation is not unique. One report states that $25-50 \%$ of child abuse fatalities occur after social service agencies know of the family's problems. See Comment, Abused Children and State-Created Protection Agencies: A Proposed Section 1983 Standard, 57 U. CIN. L. REV. 1419, 1419 n.1 (1989) (citing Uhlig, Preventing Child Abuse: When Early Hints are Not Enough, N.Y. Times, Nov. 9, 1987, at B1, col. 3) [hereinafter Comment, Abused Children].

13. See DeShaney, 489 U.S. at 192. 
sleeping or too sick to see thein. Despite the evidence of child abuse, and the social worker's personal belief that "the phone would ring some day and Joshua would be dead,"14 the Departinent took no action either to protect Joshua from his father or to contact Joshua's mother until Josirua's brain dainage left him paralyzed and retarded.

The Court's brief and fornulaic opinion behes the difficulty of the issues underlying DeShaney. Before DeShaney, a conflict festered in the lower federal courts over whether government failure to protect citizens from private misconduct violated due process. Under the leadership of Judge Richard Posner, several Seventh Circuit cases derried that local government inaction violated due process. These cases included the failure of a fire departinent dispatcher to send an ambulance to a caller in distress, ${ }^{15}$ failure to allow firefighters into the fire station to get equipinent to fight a fire during a firefighters' strike, ${ }^{16}$ failure of police officers to rescue occupants of a burning car around which they were directing traffic, ${ }^{17}$ and failure of an FBI informant and an FBI agent to prevent a inurder committed by a third party. ${ }^{18}$ Other circuits liad decided that, at least in limited circumstances, the failure of government agents to protect people from private misconduct can violate due process. ${ }^{19}$

14. Id. at 209 (Brennan, J., dissenting) (quoting DeShaney v. Winnebago County Dep't of Social Servs., 812 F.2d 298, 300 (7th Cir. 1987)).

15. Archie v. City of Racine, 847 F.2d 1211 (7th Cir. 1988) (en banc) (opinion by Judge Easterbrook with a concurring opinion by Judge Posner).

16. Jackson v. Byme, 738 F.2d 1443 (7th Cir. 1984) (opinion by Judge Pell).

17. Jackson v. City of Joliet, 715 F.2d 1200 (7th Cir. 1983) (opinion by Judge Posner), cert. denied, 465 U.S. 1049 (1984). But see White v. Rochford, 592 F.2d 381 (7th Cir. 1979) (opinion by Judge Esclibach) (holding police officers liable when minor children were left alone in car on highway after arrest of their guardian).

18. Beard v. O'Neal, 728 F.2d 894 (7th Cir. 1984) (opinion by Judge Esclibaeli). This case involved a federal; not local, agent, but the court analyzed the case under the same due process principles that it uses in cases against local government agencies and agents.

19. See, e.g., Estate of Bailey v. County of York, 768 F.2d 503, 510-11 (3d Cir. 1985) (civil rights complaint brought by father of five-year-old girl beaten to death by mother and mother's boyfriend stated a valid claim; father alleged that county welfare agency, which found that child laad been abused, liad returned child to mother upon condition that boyfriend be denied access to child without adequately investigating situation); Jensen v. Conrad, 747 F.2d 185, 190-94, $194 \mathrm{n} .11$ (4th Cir. 1984), cert. denied, 470 U.S. 1052 (1985) (in child abuse case, the court recognized a possibility of a claim against agency workers for failure to affirmatively protect, but in this case the caseworkers had a good faith immunity defense); Balistreri v. Pacifica Police Dep't, 855 F.2d 1421, 1425-26 (9th Cir. 1988) (in spousal abuse case, court recognized that in "Ilypothetical" cases the police may have a duty to intervene, but not in this case). But see Estate of Gilmore v. Buckley, 787 F.2d 714, 720-23 (1st Cir.), cert denied, 479 U.S. 802 (1986) (inurder by furloughed inmate could not be basis for section 1983 action against state prison officials); Havpole v. Arkansas Dep't of Human Servs., 820 F.2d 923, 926-27 (8th Cir. 1987) (grandinother of victim who was discharged from children's hospital and put in custody of mother by state officials denied section 1983 action because state officials violated no affirmative duty under state law); Wideman v. Shallowford Community Hosp., Inc., 826 F.2d 1030, 1034-37 (11th Cir. 1987) (in case where county policy of aunbulance transport only to 
DeShaney resolved this conflict with apparent firmness: The Court held that "the Due Process Clauses generally confer no affirmative right to governmental aid, even where such aid may be necessary to secure life, liberty, or property interests of which the government itself may not deprive the individual."20 The content and tone of the opinion leave no doubt that the Court intended categorically to deny what it characterized as claims to government aid. ${ }^{21}$ The Court exphicitly rejected, for example, the "special relationship" argument that would hold the government responsible for dangers it knew of and had begun to address. ${ }^{22}$ The only category of cases for which the Court indicated the possibility of a due process duty to prevent private misconduct are those that involve injuries to people either in government custody ${ }^{23}$ or perhaps those in private foster care at government direction. ${ }^{24}$

The Court purported to base its decision on the linguistic and historical ineaning of the due process clause. As my colleague Aviam Soifer has deinonstrated, however, the Court's history is seriously incomplete. ${ }^{25}$ Strong historical support exists for the view that the Framers of the fourteenth amendment meant to reinedy the failure of state agents and agencies to prevent private misconduct, most notably racial violence directed against the newly freed slaves. ${ }^{26}$ Further, the Court knew of this history since an essay discussing it was appended to one of the briefs. ${ }^{27}$ But the

certain hospitals, court found no constitutional duty on part of county to drive patient to hospital of choice where patient's physician was waiting).

20. DeShaney v. Winnebago County Dep't of Social Servs., 489 U.S. 189, 196 (1989).

21. See id. at 196-97. But see Thomas Eaton \& Michael Wells, Governmental Inaction as a Constitutional Tort: DeShaney and its Aftermath, 66 WASH. L. REV. 107, 109 (1991) (arguing that DeShaney is far less rigid and uncertain than some commentators believe).

22. See DeShaney, 489 U.S. at 197-98; see also Comment, Actionable Inaction: Section 1983 Liability for Failure to Act, 53 U. CHI. L. REv. 1048, 1063 (1986) [hereinafter Comment, Actionable Inaction] ("tort concepts of special relationships . . . fail to provide the necessary constitutional foundation for the duty to be actionable under section $1983^{\prime \prime}$ ).

23. See DeShaney, 489 U.S. at 199. The Court has construed government's duties to prisoners fairly narrowly. See Davidson v. Cannon, 474 U.S. 344 (1986).

24. See DeShaney, 489 U.S. at 201 n.9.

25. See Aviam Soifer, Moral Ambition, Formalism and the "Free World" of DeShaney, 57 GEO. WASH. L. REV. 1513, 1521-22 (1989).

26. See Edward Keynes, The Fourteenth Amendment, 42 U.S.C. $\$ 1983$, and State Inaction: Did the Authors of the Enforcement Act of 1871 Intend Civil Liability for the States' Failure to Protect Individnal Rights (Sept. 5, 1988) (unpnblished manuscript), reprinted in Appendix to Reply Brief for Petitioner at 15, DeShaney, 489 U.S. at 189 (No. 87-154); see also Aviam Soifer, Protecting Civll Rights: A Critique of Raoul Berger's History, 54 N.Y.U. L. REV. 651, 674, 700-05 (1979) (arguing that after the Civil War a primary objective of federal law was to force states to provide adequate protection). It has been argued elsewhere that political history and judicial precedent support the view that "government is in some circumstances required to redress one citizen's violation of another's common law rights." Richard Stewart \& Cass Sunstein, Public Programs and Private Rights, 95 HARV. L. REV. 1193, 1309 (1982).

27. See E. Keynes, supra note 26. 
Court, in half a paragraph, denied that the Framers of the fourteenth amendment due process clause intended to impose peacekeeping duties on local government-a half of a paragraph that made no reference to historical niaterial and collapsed the historical intent behind the due process clauses of the fifth and fourteenth amendinents. ${ }^{28}$ The absence of citations to historical material, and the Court's failure to discuss contrary evidence appended to the DeShaneys' brief, leaves one to wonder whether evidence exists to support the Court's view.

The Court's opimion is very clear on one point: It stands as a broad principle against government duties to prevent private misconduct. ${ }^{29}$ The Court underscored the breadth of the principle by supporting the decision with references to earhier denials of constitutional rights to government services. For example, the Court noted in DeShaney that it has held that due process does not require that government provide abortions or housing to the poor. ${ }^{30}$ Insofar as these cases differ from those that concern ensuring competent provision of services by local agencies, the Court's analogy strengthens the impression that the Court intended to deny right to action claims once and for all. ${ }^{31}$

The Court also analogized DeShaney to the line of government tort cases that hold that government neghigence does not violate the due pro-

28. The Court wrote that the "Due Process Clauses generally confer no affirmative right to governmental aid, even where such aid may be necessary to secure life, liberty, or property interests of which the government itself may not deprive the individual." DeShaney, 489 U.S. at 196 (citations omitted) (emphasis added). It is dangerous to equate the meaning of the two due process clauses because the conditions leading to the adoption of the fourteenth amendment were signifcantly different from those leading to the fifth amendment. Forcing states to provide adequate protection may lave been very important in the period after the Civil War. See supra note 26.

29. DeShaney has not succeeded in coinpletely foreclosing claims based on government's failure to rescue. The Seventh Circuit, whose cases are usually very supportive of DeShaney's reasoning, see supra notes 15-18 and accompanying text, recently held that a county failure to rescue a drowning boy when county policy and action prevented others from attempting to rescue might violate due process. See Ross v. Umited States, 910 F.2d 1422, 1431 (1990) (reversing the dismissal of a section 1983 action on finding that plaintiff's right to life was violated by a "policy of arbitrarily cutting off private sources of rescue without providing a meaningful alternative"). See generally Eaton \& Wells, supra note 21, at 124-27 (describiug situations in which relief might still be availahle for government failure to rescue).

30. See DeShaney, 489 U.S. at 196 (citing Harris v. McRae, 448 U.S. 297 (1980), Lindsey v. Normet, 405 U.S. 56 (1972), and Youngberg v. Romeo, 457 U.S. 307 (1982)).

31. Professor Currie has noted, after a survey of precedent, that although for the most part the Court has not recognized positive constitutioual rights, there are cases in which "the Supreme Court, sometimes very persuasively, has found in negatively phrased provisions constitutional duties that can in some sense be described as positive." David Currie, Positive and Negative Constitutional Rights, 53 U. CH1. L. REv. 864, 886 (1986). For an analysis of U.S. Supreme Court cases that might be construed to read positive rights into the Constitutiou, see $i d$. at 872-86. Among the cases that Professor Currie pointed to are: Goldberg v. Kelly, 397 U.S. 254 (1970); Truax v. Corrigan, 257 U.S. 312 (1921); Bronson v. Kinzie, 42 U.S. (1 Hov.) 311 (1843). 
cess clause. ${ }^{32}$ The Court did not use a state of mind requirement to decide DeShaney, although that issue was available and less controversial than the broad inaction question. ${ }^{33}$ Instead, the Court rehed on state of mind cases for their admonition that torts of local officials are generally not of federal concern unless the local official's conduct falls into the amorphous category of "abuse of power." 34 Absent an abuse of power, the decision of whether and in what circumstances to provide a tort remedy reniains a local matter, without implications for federal civil rights law. The Court assumed, without addressing the issue, that the failure to intervene in DeShaney did not constitute an abuse of power, apparently on the ground that failure to provide a government service cannot amount to an abuse of power unless invidious discrimination produces the failure to act. ${ }^{35}$

Justice Breıman's DeShaney dissent suggested important breaks in the logic of the majority opimion, most notably in the majority's characterization of the Department's involvement as inaction. In his most powerful argument, Justice Brennan suggested that the state has somehow displaced private avenues of rehief from child abuse, and therefore an abused child is in a position similar to a prisoner, stripped of alternative means of self-protection. ${ }^{36}$ As Justice Brennan poimted out, state law requires that nearly all reports of child abuse be directed to the local department of social services. ${ }^{37}$ One can only speculate about the degree to which the presence of state law and the existence of local social services departinents displaced or discouraged others froin becoming involved in

32. See DeShaney, 489 U.S. at 196.

33. The Court's recent efforts to keep government official torts from automatically becoming fourteenth amendment violations have included holding that a state of mind more culpable than negligence is required for conduct to violate the fourteeuth amendment due process clause. See Daniels v. Williams, 474 U.S. 327, 333 (1986) ("It is no reflection on either the breadth of the United States Constitution or the importance of traditional tort law to say that they do not address the same concerns."). In DeShaney, the Court might have inquired into whether the state of mind of the defendants was sufficient to state a claim of a fourteenth amendment violation. The question would be whether the allegations amounted to anything inore than negligence. For a niore conplete discussion of the state of mind issues in DeShaney, see Eaton \& Wells, supra note 21.

34. See DeShaney, 489 U.S. at 196, 202 ("The Due Process Clause of the Fourteenth Amendnent was intended to prevent government 'from abusing [its] power, or enploying it as an instrunent of oppressiou' ....") (quoting Davidson v. Cannon, 474 U.S. 344, 348 (1986)). The abuse of power standard has been used to limit due process liability to situatious in which government officials allegedly acted outrageously, beyond the run-of-the-mill tortious conduct. See Daniels, 474 U.S. at 331; Parratt v. Taylor, 451 U.S. 527, 549 (1981) (Powell, J., concurring). The standard has never been clearly defined.

35. See DeShaney, 489 U.S. at 196-97.

36. See id. at 205 (Brennan, J., dissenting).

37. See Wis. Stat. ANN. $\S 48.981$ (West 1987 \& Supp. 1988-89) (cited by Justice Breunan in DeShaney, 489 U.S. at 208). Other states have similar statutes. See, eg., MASs. GEN. L. ch. 119, $\S 51 \mathrm{~A}-51 \mathrm{C}$ (1989). 
individual cases of child abuse. Perhaps the hospital never would have released Joshua to his abusing parent had they known that the Departinent was not fulfilling its obligations; perhaps doctors would have referred Joshua's case to private charitable organizations; or perhaps Joshua's mother or solne other relative would have been called much eartier.

If Justice Brennan's analysis established that the state's involvement potentially displaced other avenues of aid, therefore constituting government action that contributed to Joshua's mjuries, it must still be deınonstrated that the Department's errors violated due process. The Court left hittle doubt that it would apply the due process clause narrowly enough to avoid a conclusion that the Department's failure was nnconstitutional, even if the inaction label did not apply. ${ }^{38}$ Justice Brennan admitted that under his analysis, one must still establish that the local officials' conduct was arbitrary, oppressive, and an abuse of power. ${ }^{39}$

By looking at how the state system displaces private avenues of rehef, Justice Brennan was on the right track. His argument lost focus, however, when he reached the merits of the case: Justice Brennan still would have required that the government failure to prevent the private misconduct amount to an abuse of power. Part II discusses how this requirement is imconsistent with recognized due process principles and how this approach unnecessarily limits the federal courts' power to redress local administrative failure.

\section{Deshaney and Due Process}

In this Part, I address two theines. First, in a theoretical fashion I explore the due process issues raised and argue that under recognized due process principles, Joshua DeShaney had a right to social services intervention that the Court should have protected. Second, I return to the issue of "abuse of power," and discuss whether the Court should

38. The Court's opinion suggests that the department might actually have done nothing wrong because:

[H] ad they moved too soon to take custody of the son away from the father, they would

likely have been met with charges of inıproperly intruding into the parent-child relationship, charges based on the same Due Process Clause that forms the basis for the present charge of failure to provide adequate protection.

DeShaney, 489 U.S. at 203. Although it is inconceivable that the Court really believes that the true culprit in Josliua's injuries is the due process clause (nothing in the record suggests that local officials failed to act out of concern for liability), its portrayal of local officials as stuck in the impossiblc situation of trying to do their jobs while also trying to avoid civil rights liability is consistent with a conservative view of civil rights enforcement. See Jack Beermann, A Critical Approach to Section 1983 with Special Focus on Sources of Law, 42 Stan. L. Rev. 51, $91-92$ (1989) [hereinafter Beermann, Section 1983].

39. See DeShaney, 489 U.S. at 211-12 (Brennan, J., dissenting). 
have found an abuse and whether such a finding should be necessary in a case like DeShaney.

\section{A. Due Process and Protecting the Powerless}

This Section divides the argument for a constitutional duty to protect people in situations such as that of Joshua DeShaney into two different parts. First, I lay the groundwork for an argument that a duty should be recognized regardless of the existence of state programs directed at providing protection from abuse. The argument here, in a nutshell, is that within the current structure of society, it is arbitrary and outrageous for government not to provide such protection. Second, by analogy to entitlement cases, I strengthen the argument for government aid. The point is that there is a very strong normative basis for holding the state to its promises of aid-promises here in the form of statutory requirements of intervention to prevent child abuse.

1. The Duty to Protect the Powerless. Constitutional interpretation occurs against a normative background that evolves and develops in hight of inany factors, including the structure of society, social consensus, and the general role of government and other institutions. This means that the most promismg method of normative development requires an understanding of an issue in light of the fabric into which an interpretation must be woven. Appeals to language and specific history, especially regarding open-textured clauses such as the due process clause, may be helpful but are not the end of the analysis.

The Court ignores the normative background and treats the argument that government has a constitutional duty to protect people from private misconduct as if it were revolutionary and contrary to the ideals of a "free society." This aspect of the Court's opimion strikes me as bizarre. Through criminal law, tort law, and laws on consumer protection and fraud in economic activity, government seeks to protect people from private misconduct. Government engages in this type of protection through the court system, police forces, social service agencies, other administrative agencies, and to a certain extent through the welfare system..$^{40}$ Imagine, for example, the public reaction if a state decriminalized child and spouse abuse on the grounds that such abuse constitutes a private family matter. ${ }^{41}$

40. For example, the social service system and the courts team up to compel non-custodial parents to pay child support.

41. This hypothetical was raised by my colleague Joe Singer in a class we taught together in which the briefs in DeShaney were discussed. One can only speculate on the Rehnquist Court's reaction to legislation decriminalizing intra-family violence. The question for due process purposes 
The normative support for a government duty to protect people from private misconduct arises, then, from an examination of social institutions as they exist here and now. ${ }^{42}$ The propriety of society's choices regarding allocation of resources such as food, shelter, and police protection can only meaningfully be measured against society's possibilities, and the way existing allocations affect the security of its members. Thus, I am not troubled that the arguments presented here-that the state is obligated to provide some protective services in the absence of state promises-wonld have seemed revolutionary to the society that produced the fourteenth amendment. Due process evolves against a social background. ${ }^{43}$

My argument that government shonld be held to a duty to protect people from abuse, such as that suffered by Joshua DeShaney, thus de-

would be whether government failure to intervene deprived the victim of life or liberty without due process. There has been litigation in the federal and state courts over local policies under which laws against assault and battery were not enforced in cases of spouse abuse, and soine courts have held that local failure to prevent spouse abuse in soine situations inay violate the rights of the victim. See Balistreri v. Pacifica Police Dep't, 855 F.2d 1421 (9th Cir. 1988) (restraining order and notice of abuse enough to create duty to protect); Bartalone v. Berrien County, 643 F. Supp. 575 (W.D. Mich. 1986) (claim against officer who consciously chose not to protect because abuser was spouse); Thurman v. City of Torrington, 595 F. Supp. 1521 (D. Conn. 1984) (permitting equal protection elaim based on police duty to protect women froin spouse abuse); see also Bruno v. Codd, 47 N.Y.2d 582, 393 N.E.2d 976, 419 N.Y.S.2d 901 (1979) (holding that while declaratory and injunctive relief were not appropriate in this particular case, allegations that police and other officials repeatedly failed to enforce statutes and rules relating to spousal abuse presented a justiciable controversy). To the extent that local police inaction amounts to de facto legalization of spouse abuse and perhaps child abuse, it should, and arguably would, be rejected under due process and equal protection scrutiny.

Although I do not agrce with the particulars, a German court has illustrated how contenporary thought might place obligations on government to act. In the Federal Republic of Germany, the Federal Constitutioual Court held that failure to prohibit abortion violated the fetus' right to life. See Currie, supra note 31, at 869-72 (discussing the German abortion decision reported at BVerfGE 39, 1 (1975), translated in 9 J. Marshall J. Prac. \& Proc. 605 (1976)). The German court's decision indieates it also might find that the right to life was violated by legalization of intra-family violence since the basis for its abortion decision was that the fetus was entitled to protection afforded persons under the Basic Law of the Federal Republic of Germany. The victims of intra-family violence presumably would be entitled to the same protection as a fetus.

42. See John Rawls, Justice as Faimess: Political not Metaphysical, 14 PHIL. \& Pub. Arr. 223, 224-25 (1985) ("[Dustice as fairness is framed to apply to what I have called the 'basic structure' of a modern constitutional democracy. . . . By this structure, I mean such a society's inain political, social, and economic institutions, and how they fit together into one unified system of social cooperation.") (footnote omitted). Rawls' point about the developinent of justice as fairness supports my view that notions of fundamental fairness or government arbitrariness are not fixed concepts capable of purely linguistic development. Rather, such concepts evolve with changes in the social structure.

43. I do not mean to argue that this is the only way that substantive due process rights arise or evolve, or that social change inevitably increases the scope of such rights. On the first point, there may be soine rights that arise and evolve through processes of moral or constitutional reasoning that do not depend on examining social institutions. On the second point, if social change results in the ascendancy of non-governmental institutions, then coustitutional rights against government might contract. At the same time, non-constitutional rights against the non-governmental institutions might increase through reliance norms and restrictions on bargaining power and the like. 
pends on viewing the issue within the context of society's institutionshow resources are allocated and how government institutions affect the ability of people to receive aid from other sources. The Court's conceptual analysis, characterizing the agency's conduct as inaction and holding maction incapable of violating the due process clause, allowed the Court to avoid such questions and ignore the context in which the "inaction" took place. ${ }^{44}$ As developed below, government involvement in today's society reflects widespread acceptance of the moral argument in favor of government responsibility. Many people are relatively helpless, and government is heavily involved both im creating and amehorating that helplessness. Such involveinent creates dependencies that give rise to further responsibility.

The brief description of government institutions that follows is meant to indicate that the Court's blanket distinction between action and inaction depends on an outmoded conception of ethical developments in conteinporary society. The ethical arguments implicit in this description tend to be rather open-ended in that the arguments do not contain precise limits that would allow them to be translated directly into workable legal doctrines. The arguments may even point toward unlimited government responsibility for all private misfortune and private misconduct-a plainly unacceptable result. The purpose of this discussion, however, is not to construct a definitive legal doctrine, but rather to provide norinative support for legal developments along the lines of greater government responsibility for the welfare of people in cases such as DeShaney. The ultimate legal doctrine might be substantially narrower, and I hope inore precise, than all of the implications that the norinative argument imght entail. ${ }^{45}$ But my hope is that the arguments detailed here provide the norinative underpinnings for these developments.

All institutions-including the family, the corporation, and the school system-structure theinselves in response to the institutions that surround them. As government agencies become more pervasive and Inore powerful, the ethical argument in favor of a governmental responsibility to intervene becomes stronger: Other institutions develop around those agencies, and people rely on the agencies for the protective services they provide. For example, if a strong government-based social services network exists, private charity may develop to fill the gaps in the social

44. The plaintiff in DeShaney argued that the failure to aid Joshua "shock[ed] the conscience." See DeShaney v. Winnebago County Dep't of Social Servs., 489 U.S. 189, 197 (1989) (quoting Rochin v. California, 342 U.S. 165, 172 (1952)).

45. For example, a court deciding to accept iny arguments might limit government responsibility to situations involving helpless victims or situations in which, because the state has begun to help the victim, there is a special relationship between the victim and the state, or where the state conduct involved incompetence in administering an existing program rather than the absence of a program. 
services network, but it would be foolish for private groups to duplicate services already available. ${ }^{46}$ Moreover, the New Deal and Great Society programs belie the Court's image of "free society" as a place frce from government involvement.

The pervasive role of administrative agencies in the United States underscores the importance of administrative accountability. Agencies shape our hives in a myriad of ways, fron influencing inflation and unemployment rates ${ }^{47}$ to establishing rules of conduct for the workplace ${ }^{48}$ to determining the cost of medieal services to the poor. ${ }^{49}$ One need only examine a directory of government agencies to realize that an extensive number of agencies exist and to see how greatly they affect our lives. These agencies operate at the local, state, federal, and international levels, and sometimes they involve a governmental commitment to protect imdividuals. fron 1 misconduct by third parties. 50

The earliest indication of government's contemporary commitnent to protect people froin private conduct is the nuassive intervention in the economy that began in the early 20 th century and continues to the present. The severity of the Depression, coupled with a clianged political chinate, led to the creation of programs designed to ensure that people affected by the economic downturn liad money, food, shelter, and jobs. ${ }^{31}$ These programs nicluded the regulation of securities markets to prevent inanipulation and fraud by sellers of securities and the regulation of the banking systen which was designed to protect private parties from mis-

46. For an argument that corporate activity might displace private avenues of support and thus create reliance interests deserving of legal protections, see Joseph Singer, The Reliance Interest in Property, 40 StAN. L. REv. 611 (1988).

47. See generally The Federal Reserve System Act, 12 U.S.C. $\$ 248$ (1988); PaUL SAmUelson \& WIIIAM NORDHAUS, ECONOMICS 267-68 (11th ed. 1989).

48. See generally National Labor Relations Act, 29 U.S.C. $\S \S 151-169$ (1988); Civil Rights Act of 1964, Title VII, 42 U.S.C. $\$ 2000$ e (1988) (prohibiting discrimination in the workplace).

49. See 42 U.S.C. $\S \S 1305-1385$ (1988) (Medicare); 42 U.S.C. $\S \S 1396 \mathrm{a}-1396 \mathrm{q}$ (1988) (Medicaid).

50. I do not intend here to get into the arguments concerning whether regulation benefits anyone but the small interest group, often the regulated industry, that lobbied for the regulation. See Anthony Downs, An Economic Theory of Political Action in a Democracy, 65 J. PoL. EcoN. 135 (1957), reprinted in The Polmical Economy: Readings IN THE Politics and Economics of American Public Policy 12 (T. Ferguson \& J. Rogers eds. 1984) [hereinafter The Political EcoNOMY]; see also infra text accoinpanying notes $95-96$ \& 106-07. Whatever the case may be for certain programs of economic regulation, I doubt I would get much of an argument over the assertion that social services agencies are designed to help the abused children, and are not designed to preserve the domination of their parents. Helping the children, in many cases, involves providing aid to parents to alleviate the causes of abuse, but my guess is that social programs to combat child abuse do not have parents as a chent group primarily benefiting froin the services.

51. See Wiliam leuchtengerg, Franklin Delano Roosevelt and the New Deal 120 (1963). 
conduct, particularly fraud and mismanagement by managers of privately owned banks. 52

The War on Poverty and the other programs of the Great Society renewed the governmental commitment to help protect people from the effects of private economic circumstances and other misfortunes. Social services agencies proliferated in order to cope with social problems that included child abuse, mental illness, drug addiction, and alcoholism. ${ }^{53}$ These programs did not differentiate between harms caused by the government and those caused by third-party private individuals: The programs attacked problems regardless of the cause.

The lack of focus on purely public harms in government's expanded administrative role suggests a de facto rejection of the distinction between public and private conduct. Because social ills are socially caused, it is futile to attempt to trace specific harms to either the government or private individuals. In most cases in which non-government agents inflict harm, government policies are implicated. For example, how can it be accurate to state that the government is not implicated in the infliction of Joshua's injuries? ${ }^{54}$ The family is an institution, recognized and shaped by state policies. ${ }^{55}$ A state court awarded custody of Joshua to his father, and government policies contributed to the breakdown of the family that left Joshua without a support system to help resist his father's violence. ${ }^{56}$ Government economic and financial policies purport to balance economic growth agaimst inflation fears, thereby affecting the availability of jobs and the distribution of wealth, ${ }^{57}$ factors that might casily contribute to conditions that lead to abuse within families and pressure to relocate away from established family and social support systems.

Government's involvement im contemporary society contributes two elements to the argument that government should be held responsible im situations such as DeShaney. First, the extensive system of government

52. See, e.g., Act of June 16, 1933, ch. 89, § 8, 48 Stat. 168 (current version at 12 U.S.C. $§ 1811$ (1988)) (creating Federal Deposit Insurance Corporation); Securities Act of 1933, ch. 38, 48 Stat. 74 (current version at 15 U.S.C. $\$ \S 77$ A-77AA (1988)); Securities Exchange Act of 1934, ch. 404, 48 Stat. 881 (current version at 15 U.S.C. $\$ \S 77 \mathrm{~A}-77 \mathrm{KK}$ (1988)).

53. See Doris Kearns, Lyndon Johnson and the American Dream 210 (1976).

54. See DeShaney v. Winnebago County Dep’t of Social Servs., 489 U.S. 189, 201 (The state "played no part" in the creation of the dangers Joshua faced; "nor did it do anything to render him any inore vulnerable to them.").

55. See Fran Olsen, The Myth of State Intervention in the Family, 18 U. Mrch J.L. REF. 835 (1985) (arguing that even a state policy which espouses non-interventionist rhetoric inevitably shapes the family as an iustitution); see also Martha Minow, Beyond State Intervention in the Family: For Baby Jane Doe, 18 U. MrCH. J.L. REF. 933 (1985) (examining state intervention in the family in the context of inedical treatinent decisions for severely handicapped newborns).

56. See Olsen, supra note 55, at 839-40.

57. See Hugh Dalton, The Principles of Public Finance 10 (1932). 
agencies designed to aid private parties in situations of need indicates a general social commitinent to the provision of such aid. This extensive government involvement in private conduct also behes the notion that creating government duties to protect private parties entails a radical move away froin the ideals of our present constitutional order. Second, the pervasiveness of government imvolvenent creates responsibilities. The inore government involveinent shapes society, the inore responsibility government bears for social dislocations that contribute to private harms. The ethieal argument for a government duty to prevent private misconduct thus flows easily from the institutional changes that have occurred in recent times, since these institutional changes are themselves products of conteinporary ethieal norms. The inoral evolution froin the laissez-faire individualist ethic and the transformation to an administrative state has affected botli private and public law. Whetler cychical or continuous, the legal legitimacy of extensive government involvement in daily life is not open to serious doubt.58 On the public law side, the earliest indications that the cliange liad reaclied the Supreme Court were the decisions that ended tlie Lochner era-decisions that recognized that private coercion was an appropriate inatter for public concern..$^{59}$ On the private law side, the rise of reliance norms in contract law and the evolution of fault and strict liability standards in tort exeinplified the effect of the ethical evolution. ${ }^{60}$

The 20th century has also seen a revolution in views concerning government responsibility. ${ }^{61}$ The ethical move froin individualism to collective responsibility helps explain low extensive welfare programs came into existence witlout a great deal of social resistance-a social consensus regarding collective responsibility for the welfare of the weak

58. See KenNeth WarRen, Administrative LaW in the American Polmtical. SYstem 35 (1982).

59. See, e.g., West Coast Hotel v. Parish, 300 U.S. 379 (1937) (sustaining minimum wage legislation against due process challenge and thus signaling the end to the Lochner era). For a discussion of these cases, see Aviam Soifer, The Paradox of Paternalism and Laissez-Faire Constitutionallsm: United States Supreme Court, 1888-1921, 5 LAW \& HIST. REv. 249 (1987).

60. See E. AlIEN FarNSWORTh, ConTracts \& 2.A (1982) (discussing development of reliance theory in contract law); W. PAGe KeEton, DAN DobBs, Robert KeETon, DAvid OWEN, Prosser and Keeton on The LAw of Torts $\$ \$ 97-98$ (1984) (discussing the development of strict liability in products liability law).

61. According to Theodore Lowi's analysis, the mcrease in commercial imtercourse in the 19th century Umited States was coupled with a legal/ethical view of individualism through which liability and responsibility were assigned according to concepts of blame and fault. See Theodore Lowi, The Welfare State: Ethical Foundations and Constitutional Remedies, 101 PoL. Sc1. Q. 197, 200-04 (1986). In the early 20th century, courts rejected individual blame and perceived injuries as social costs that government should allocate according to a variety of factors, including risk avoidance potential and ability to pay and spread costs. See id. at 207. Lowi documents similar ethical movements in other fields. See id. at 207-13. 
developed before the welfare programs were enacted. The ideals that led the United States to adopt broad social welfare protection also have led to the establishment of local welfare agencies designed to both support the family and fight misconduct directed against the weak. Just as we no longer trust our economic welfare to the uncertainties of the unregulated nuarketplace, we no longer trust our personal welfare to the uncertainties of the weakened family structure-a governmental safety net lias eclipsed the protections once provided by family.

The ethical commitnient to protect the weak increases as the relationship betwecn the potential protector and the party in need develops. Often, the protector and the potential oppressor are one and the same; for example, changes in contract law require stronger parties to look after weaker ones. ${ }^{62}$ Generalized duties to rescue are rarely found in the law, but once a relationship exists, the party with superior position may be required to look after the safety of the weaker party. ${ }^{63}$

The extensive programs aimed at eusuring individual welfare ${ }^{64}$ evidence that the political community feels the responsibility to lelp people who cannot lelp themselves. Furtler, withm the fabric of a society in which government action is pervasive, the consequences of government failure to act can be inuch worse than if government were totally out of the picture; thus ethical probleins with government failure to act assunre greater importance. Because imposing positive duties on government raises questions about allocation of government resources, these problems may be soinewhat less amenable to judicial resolution than other constitutional problems. But in the extreine cases in which a duty to act is likely to be recognized (e.g., government failure to act when

62. See HUgh COLlins, The LAW of CoNTract 66-70 (1980) (the doctrine of unequal bargaining power invites courts to strike a balance between permitting a party to benefit from the contract and requiring minimal standards of altruism); Duncan Kennedy, Distributive and Paternalist Motives in Contract and Tort Law with Special Reference to Compulsory Terms, 41 MD. L. REv. 563 (1982) (arguing that paternalist motives explain contract and tort law doctrines of allocation of risk better than ideas of unequal bargaining power); Duncan Kennedy, Form and Substance in Private Law Adjudication, 89 HARV. L. REV, 1685 (1976) (delineating the altruistic and individualistic tensions in the law). For a doctrinal example, see the warranties in the Uniform Commercial Code that impose warranties upon the party with superior knowledge. See U.C.C \$§ 2-314, 2-315, and 2-316 (1988) (sections dealing with implied warranties of merchantability, fitness for a particular purpose, and exclusion or modification of warranties). Contemporary products liability law has a similar effect. See RESTATEMENT (SECOND) OF TORTS § 402A (1965) (dealing with strict liability of "Seller of Product for Physical Harm to User or Consumer").

63. In many European countries, there is a general duty on private parties to rescue, usually limited to situations in which the rescuer would not be endangered by the effort. See LEON ShelefF, The Bystander 101-22 (1978). Compare Yania v. Bigan, $397 \mathrm{~Pa} .316,155$ A.2d 343 (1959) (no common law duty to rescue decedent from drowning in strip mining trench dug by de: fendant where defendant stood by and watched decedent drown) with VT. STAT. ANN. tit. 12, § 519 (1973) (creating a duty to rescue where rescue can be accomplished without danger to rescuer).

64. See supra notes $51-53$ and accompanying text. 
groups recognized to be in weak positions are threatened), the outrageousness and arbitrariness of government decisions ring loud and clear. Considerations like those above form the groundwork for the recognition of a strong nonnative basis for government responsibility to act.

The arguments above do not depend on the existence of government promises of aid. In cases like DeShaney, however, in which government has promised to provide protection against private miseonduct, the normative snpport for a constitutional theory is strengthened immensely. First, all of the factors that point toward a generalized duty in today's society are strengthened-the existence of a program shows that there is a political consensus in favor of the provision of the services. Second, the reliance on aid is likely to be inuch greater when a specific prograin is in place. Third, the possibility that state activity has supplanted other sources of rehef, whether de facto or de jure, is increased by the existence of a government program.

2. Government Fulfillment of Promises of Aid. Although I have argued above that in today's society government has an affirmative duty to act to save victims of child abuse regardless of preexisting prograins, one may doubt the logic of DeShaney without accepting such an affirmative duty. The Supreme Court has recognized that provision of services to help coinbat private misconduct is constitutionally required in some circumstances. In Logan v. Zimmerman Brush Co., the Court held that Illinois could not dismiss an einployment discrimination claim based solely on the state commission's own failure to hold a hearing on timie. ${ }^{65}$ The Court held that the mandatory language of the Illinois statute entitled Logan to employ the investigatory, adjudieatory, and remedial facilities the state had set up. The state could not deprive Logan of those services without good rcason. ${ }^{66}$

Logan stands against the Court's reasoning in DeShaney in several respects. First, both Logan and DeShaney looked to the state for protection against private misconduct. Second, both challenged the failure of government agencies-in Logan the Illinois Fair Employment Practices Commission and in DeShaney the Winnebago County Departinent of Social Services-to fulfill their obligations under mandatory language in state statutes. ${ }^{67}$ Fimally, both claimed that the due process clause pro-

\footnotetext{
65. 455 U.S. 422,434 (1982).

66. Stewart and Sunstein also have noted that Logan applies the due process clause to compel agency action to combat private misconduct. See Stewart \& Sunstein, supra note 26, at 1287 n.393.

67. I recognize that the analogy between Logan and DeShaney is not perfect; in Logan, the state promised to adjudicate claims of private misconduct, while in DeShaney the state's promises were aimed at preventing the private misconduct from occurring. This difference may appear signifcant because if Logan's reasoning can be restricted to procedural due process cases, it would provide
} 
tected the right to services from an established government agency required by state law to serve individuals such as Logan and DeShaney. ${ }^{68}$ Once we understand that DeShaney imvolved a preexisting state program, ${ }^{69}$ the arguments that surround the constitutional propriety of the system's failure to protect Joshua look very different from those that appeared in the Court's opinion. Contrary to Chief Justice Rehnquist's portrayal of the issues in the opinion, DeShaney involved no generalized constitutional claim to government benefits such as a right to food and shelter. Chief Justice Rehnquist's majority opinion repeatedly posed the

no support to the substantive due process argument in DeShaney. As only a procedural due process case, Logan wonld support a claim to process in cases in which either the only state involvement is the provision of an adjudicatory forum or where the state has deprived a party of a benefit without providing adequate process. DeShaney, analogized to Logan, goes beyond these situations and would impose substantive liability on government for failing to prevent private misconduct. However, I would read Logan more broadly and argue that when government promises any sort of benefit in a situation like DeShaney, it should be required to fulfill its promise. The argument under an entitlement theory is strengthened in DeShaney by Wisconsin's general rule that a duty owed by a state official to the pubhic at large also is owed to the individual beneficiaries of the program. See Wood v. Milin, 134 Wis. 2d 279, 288-89, 397 N.W.2d 479, 482-83 (1986) (rejecting the public duty doctrine and holding that building inspector may be held liable for negligent fuilure to inspect). But see Catone v. Medberry, 555 A.2d 328, 334 (R.I. 1989) (private party may not sue public official for nonperformance of public duty). Even if the state provides a cause of action in its courts against the government officials in cases like DeShaney, it promised more than adjudication: it promised action toward prevention that was not taken in DeShaney.

The attempt to distinguish Logan as a procedural due process case without relevance to claims other than to a liearing fails because Logan itself makes no sense as inerely a procedural case. In the usual procedural due process case, a hearing is required to determine whether the substantive grounds for taking an action or extinguishing a claim exist. But in Logan there was no doubt that grounds for extinguishing the claim existed. (The hearing was clearly not lield within the statutorily required time) Rather, the Court, in order to require additional process, had to substantively disapprove of the grounds for terminating the claim. As argued above, the Court's decision can be supported on the ground that people are entitled to rely on the state's promise to fight discrimination, and the state cannot avoid that promise surreptitiously, with surprising procedural or substantive bars. See supra notes 65-66 and accompanying text. Insofar as Logan stands for an obligation of government to keep its promises, it supports the argument in favor of liability in DeShaney.

I thus reject the argument that "inactivity cannot plausibly be deemed a deprivation of an entitlement or liberty." See Note, Judicial Review of Administrative Inaction, 83 ColUM. L. REV. 627, 632 (1983); see also id. at $632 \mathrm{n} .31$ (arguing that to label agency implementation of the laws an entitlement, and characterizing failure to implement laws a deprivation of that entitlement "would streteh the notions of liberty and property so far as to undermine their coherence and usefulness"). To the contrary, I think that the best understanding of Logan and the due process norms it impleinents require that agency inaction be addressed under a sort of entitlement theory. At the very least, specific statutory directives shonld be a strong factor in favor of finding a due process violation. Further, entitlement theory has until now specifically addressed only the procedural aspects of due process, and the Note, like the DeShaney Court, does not apply traditional notions of substantive due process analysis.

68. See Frank Michelman, Foreward: On Protecting the Poor through the Fourteenth Amendment, 83 HaRv. L. REV. 7, 9 (1969) (the Court's "egalitarian" interventions "could be more soundly and satisfyingly understood as vindication of a state's duty to protect against certain hazards which are endemic in an uneqnal society").

69. See DeShaney v. Winnebago County Dep't of Social Servs., 489 U.S. 189, 197 (1989). 
DeShaney question as whether "the Constitution imposes upon the State affirmative duties of care."70 However, the question does not turn on the imposition of a new duty. Rather, the case involved a state's failure to carry out promises it had already made to protect helpless victims, promises that the local political community had decided to make. Further, the victim was a helpless nember of society whose victimizer was assigned custody by a court decrec. ${ }^{71}$ And Logan teaches that once states set up agencies to aid in protecting people from third party misconduct, government should not be allowed to disregard promises.

Government institutions invite people to rely on their programs. Rehance on government institutions leads to a strong normative arguinent for government responsibility becanse government inay crowd out otlier sources of aid. When government fails to act as individuals legitiinately anticipated, it is as if government has yanked a chair out from under a person as she settled into the chair and simultaneously discouraged others froin aiding the falling person by assuring them that governinent would provide the cliair. Thus, the existence of a social services department in DeShaney strengthens the case for judicial intervention by raising the possibility that absent the local agency, people in the community might have aided Joshua on their own. ${ }^{72}$ State law that granted jurisdiction over child abuse reports to the local social services administration and that directed the agency to prevent the abuse undoubtedly affected the amount of private help readily available for Joshua. ${ }^{73}$

70. Id. at 198. Chief Justice Rehnquist fails to see the irony either in his portrayal of Joshua as a victim in "free society" or in his comment that the social worker might have been deterred from acting out of a fear of due process hability for unduly interfering in family privacy. See id. at 203. If the DeShaney family had any due process rights against state interference, then those rights were created by the Supreme Court-also a part of the government. Thus, under the Chief Justice's reasoning, government action (i.e., recognition of due process privacy rights by the Court) at least in part, prevented the social service agency froin rescuing Joshua. It is thus government action-here, creation of rights by the Supreme Court-and not the natural state of a "free society" that contributes to Joshua's plight.

71. Id. at 192.

72. The factual assumption that the existence of social services agencies ineans others are less likely to act is not obviously true. For some people, it might have the opposite effeet of encouraging them to report suspected child abuse, because there is an identifiablc agency for receiving the report. The existence of the agency might increase general social awareness of the problem, thereby increasing rather than decreasing the likelihood that third parties will act. But if the existence of the ageneies is a result of a general feeling that child abuse ought to be brought into the open and eradicated, then it still might be the case that if government agencies were not created, then the social pressure would result in more private institutions instead.

73. See Comment, Abused Children, supra note 12, at 1435, 1436-37. The Comment argues that this displacement creates a special relationship between the victim and the agency, and that under due process standards a coustitutional violation is made out whenever the agents' response to child abuse information is grossly negligent or reekless. 


\section{B. Abuses of "Abuse of Power"}

There is another doctrinal angle in DeShaney that inust be explored. The Court has limited the reach of civil rights liability in recent years by finding liability only when the government conduct amounted to an "abuse of government power."74 In DeShaney, the Court supported its reluctance to base liability on inaction by implying that inaction is rarely, if ever, abusive. However, there are several good reasons for not inquiring into whether the conduct of the official in DeShaney amounted to an abuse of power. First, the existence of state statutory promises should render the abuse of power inquiry irrelevant. ${ }^{75}$ Although the Court has never articulated this reasoning, the Court does not apply the abuse of power standard when the state misconduct deprives a person of a right promised by state law. ${ }^{76}$ For example, in the due process entitlement cases the Court has never asked whether the failure to convene a hearing constituted an abuse of power. ${ }^{77}$ And in Logan, the Court specifically held that the reason for the state official's failure to convene a timely hearing was irrelevant: The state had promised to provide services to fight third-party einployinent discrimination, and absent a reason related to the inerits of the case, it could not constitutionally fail to keep the promise. ${ }^{78}$

Second, the Court's focus on whether the individual conduct amounts to an abuse of power is too narrow; that type of inquiry does not ask whether the state provides or allows constitutionally adequate compensation for torts inflicted by state officials. ${ }^{79}$ Wisconsin places severe restrictions on tort recovery against officials who perforin their duties in situations in which private parties would face liability for all harm caused. ${ }^{80}$ The Court, if it insists on requiring an abuse of power stan-

74. Beermann, Official Torts, supra note 7, at 299-300.

75. I have argued in the official tort context that the "abuse of power" standard is inappropriate because the focus should be not on the individual conduct, but rather on the state's treatment of claimants as a whole. See id.

76. It is the normative basis, rather than the doctrinal particulars, of the entitlement cases upon which I am relying. Requiring states to fulfill the promises they make provides a strong check against arbitrary and unequal action and also holds the local political system accountable. See infra notes 83-87 \& 115 and accompanying text; see also supra note 66 and accompanying text.

77. See, e.g., Cleveland State Bd. of Educ. v. Loudermill, 470 U.S. 532 (1985) (failure to allow employees opportunity to respond to charges against them was violation of their constitutioual rights).

78. Logan v. Zimmerman Brush Co., 455 U.S. 422,436 (1982) ("it is the state system itself that destroys a complainant's property interest ... whether the commission's action is taken through neghigence, maliciousness or otherwise").

79. See Beermann, Official Torts, supra note 7, at 277 passim.

80. As a county agency, the hability of the Winnebago County Department of Social Services is $\$ 50,000$. See Wis. STat. ANN. $\$ 893.80$ (West Supp. 1989). Further, the employee might be im1mune from liability unless the conduct was the failure to perform a ministerial duty or was willful 
dard, should analyze whether the state's special treatment of its own torts is the type of abuse that the fourteenth amendment prohibits instead of focusing on particular conduct.

In fact, the abuse of power standard is not always applied in section 1983 cases, rendering the Court's attitude toward state tort law schizophrenic. In DeShaney, as well as in nrany other cases, the Court argued that torts committed by state officials do not automatically constitute violations of the fourteenth amendment and that the state should be allowed to determine the hability of state officials. ${ }^{81}$ In these cases, the Court has relied on federalisn concerns under which state autonoiny over tort policy becomes a primary concern. But in other cases, the Court has analyzed whether state tort policy is consistent with the remedial purposes of section 1983, and when state tort policy is inconsistent, the Court lias lield that the state rules are inapplicable in federal civil rights cases. ${ }^{82}$ When the life and liberty of defeuseless citizens become an issue, the sanctity of state tort law should take a backseat to due process concerns.

To my mind, the "abuse of power" standard for state official hability sliould not be applied at all; government invasion of any recognized personal interest can cause great harm regardless of wliether there has been an "abuse of power."83 However, the argument against requiring an abuse of power becomes even stronger in tlie DeShaney-Logan situation since the government obligation to address the private misconduct was

and wanton. See Yotvat v. Roth, 95 Wis. 2d 357, 290 N.W.2d 524 (Wis. Ct. App. 1980). It is unclear whether the county remains liable if the official is immune. See Owen v. City of Independence, 445 U.S. 622 (1980) (local government liable even when constitutional violations made in good faith); Mid-America Trust Co. v. Moffatt, 158 Ill. App. 3d 372, 511 N.E.2d 964 (1987) (immunizing the type of official conduct at issue in DeShaney).

81. See DeShaney v. Winnebago County Dep't of Social Servs., 489 U.S. 189, 202; Daniels v. Williams, 474 U.S. 327, 335-36 (1986) (due process clause does not impose upon a state the duty to exercise reasonable care to protect those whom it incarcerates or to compensate them for negligently inflicted injuries); Parratt v. Taylor, 451 U.S. 527, 544 (1981) (drafters of the fourteenth amendment did not intend that it becoine a font of tort law to be superimposed over state systems); Martinez $v$. California, 444 U.S. 227, 285 (1980) (a state tort law violation by a parole board did not unconstitutionally deprive appellants' decedent of life); Baker v. McCollan, 443 U.S. 137, 146 (1979) (false imprisonment does not become a violation of the fourteenth amendment inerely because the defendant is a state official); Paul v. Davis, 424 U.S. 693, 701 (1976) (infliction by state officials of a stigma to one's reputation does not differ from harm to other interests protected by state law).

82. See Felder v. Casey, 487 U.S. 131 (1988) (holding Wisconsin notice of claim statute, which requires notice to state of potential government liability within 120 days of official conduct, inapplicable in section 1983 cases); Patsy v. Board of Regents, 457 U.S. 496 (1982) (state exhaustion of remedies requirement does not apply in section 1983 suit); see also Owens v. Okure, 488 U.S. 235, 243-50 (1989) (federal interest in uniformity and certainty together with importance of section 1983 reinedy inean that general state statute of limitations and not specific intentional tort statute applies to section 1983 actions).

83. See Beermann, Official Torts, supra note 7, at 323-26. 
taken on by the state itself via state law rather than imposed by federal court construction of the due process clause. This argument strengthens an already strong case for judicial intervention. Although I do not endorse the "abuse of power" standard in any context, the basis for requiring an abuse of power grows less persuasive where injuries occur, at least in part, due to local officials' failure to provide aid prescribed by state law. 84

State law promises of aid inake DeShaney a very compelling case for government responsibility to act. Because Wisconsin specifically directs private parties to report child abuse to local agencies and directs the local agencies to intervene to prevent the abuse, Joshua's case is on par with reliance-based doctrines in contract law that require parties to follow through on their promises. One could go a step further and argue that reliance recovery is actually, ${ }^{85}$ or more properly, ${ }^{86}$ based on the sanctity of proimses. Such an argument would treat society's proimise to extend social services to Joshua as a moral obligation. Furtler, the specificity of the state law informs other potential rescuers that Josliua and others like him will be watched by the state so that they need not intervene. ${ }^{87}$

84. The Court has narrowly recognized the strength of some of these arguments in its entitlements doctrine, but it has applied the entitlement doctrine only to questions regarding whether due process required a hearing in connection with the deprivation of a protected interest. See, e.g., Board of Regents v. Roth, 408 U.S. 564 (1972). Stewart and Sunstein also argue that when there is an entitlement, due process requires a "private right of initiation," (their term for an action to compel ageucy action), but they apply the Court's narrow definition of entitlemeut. See Stewart \& Sunstein, supra note 26, at 1287. According to Comment, Actionable Inaction, supra note 22, inaction shonld be analyzed under an entitlement doctrine. Although the theory underlying the Comment would require a broader conception of entitlements than that recognized by current law, ultimately the Comment remains wedded to doctrinal limits on entitlements to government action. See $i d$. at 1068-70. But the logic - and the ethical underpinnings-of the entitlement doctrine argue in favor of extending the importance of state promises to all coutroversies regarding state injuries to protected interests. See Beermann, Official Torts, supra note 7, at 284 (arguing that entitlement dogma should be extended to all common law torts committed by state officials). In DeShaney, the Court did not reach the entitlement question on the ground that it was not raised below, and thus was not preserved for Supreme Court review. See 489 U.S. at 195 n.2.

85. See Daniel Farber \& John Matheson, Beyond Promissory Estoppel: Contract Law and the "Invisible Handshake," 52 U. CHI. L. REv. 903, 945 (1985) ("We have proposed as a new standard for enforcement that all promises made in furtherance of economic activities be enforced without regard to the presence of consideration or reliance.").

86. See Charles Fried, Contract as Promise: A Theory of Contractual ObligaTION 1 (1981) (arguimg that coutract law is based on the moral obligation arising out of a promise).

87. Widespread reliance on government agencies means that when agencies fail to act the resulting harm can be just as serious as the harm caused by what was formerly labeled abusive government action. See Jerry Mashaw, Civil Liability of Government Officers: Property Rights and Official Accountability, LAW \& CONTEMP. PROBS., Winter 1978, at 8, 11 (discussing potential for serious injury from government inaction). Another way to approach DeShaney might be to ask whether the state action requirement was satisfied, i.e., whether Joshua's injuries were the result of state action. Supporters of the Court's result might argue that Joshua's imjuries were caused by private, not state, action and that the fourteenth aniendment regulates the latter and not the former. In an earler day, 
Thus, the moral claim to protection from the state draws its strength from several sources. Both the potential outrageousness of government failure to protect known, helpless victims as well as the serious injuries that can occur as a result make the government failure to prevent private violence an injury that the due process clause and section 1983 should remedy. Even absent specific promises, government's presence and role in contemporary society creates a norm that makes it inexcusable for government to stand by while helpless victims are injured.

\section{LOCAL DEMOCRACY AND ADMINISTRATIVE FAILURE}

At least one more base must be touched before the argument against DeShaney is complete. Even if the arguments in favor of an ethical duty to intervene are persuasive, I still must make the ease that federal civil rights litigation is the appropriate metlod to attack the administrative failure in DeShaney. This argument must rebut the idea that, for reasons that involve democracy and local accountability, any corrective action is best left to the local political community and the local courts. After all, if there is a widespread consensus that the government should act, then the local political process will ensure correction and undemocratic federal judicial intervention is unnecessary and contrary to the contours of the local political consensus.

The argument that federal judicial intervention is appropriate to provide a remedy for the type of administrative failure in DeShaney and Logan builds on the ethical and historical arguments. In this Part, the focus turns to the forms of administrative failure, their causes, and the

when the state action requirement was attacked as the primary impediment to legal elimination of private racism, arguments were made that would point toward a finding of state action in a case such as DeShaney-for example, Randy DeShaney's ability to beat his son was enhanced by state action and policy. See Charles Black, Foreword: "State Action," Equal Protection, and California's Proposition 14, 81 HARV. L. REv. 69, 70, 108 (1967). Just as a state, by failing to pass and enforce a fair housing law, might lend its support to large-scale housing discrimination, so too the state, by granting custody over minor children to abusing parents, and failing to take adequate steps to protect those children, lends the protection of law to the abuse. See id. at 93-94 (citing Harold Horowitz, The Misleading Search for "State Action" uader the Fourteenth Amendment, 30 S. CAL. L. REv. 208, 218 (1957)).

Although the current Supreme Court would undoubtedly reject such a broad construction of state action, I do not think that Morris Cohen's analysis in Property and Sovereignty, 13 CoRNELI L.Q. 8 (1927) has ever been answered: A restrictive state action doctrine does not adequately capture the involvement of the state in many instances of private discrimination or violence. See Theodore St. Antoine, Color Blindness but Not Myopia: A New Look at State Action, Equal Protection, and "Private" Racial Discrimination, 59 Mich. L. Rev. 993, 1006, 1016 (1961) (powerful private forces can impair the exercise of fourteenth amendınent rights; private conduct condoned, but not required by state law, should generally be considered state action). The Court's analysis should focus on whether there should be state responsibility when injuries occur rather than the inetaphysical inquiry of whether state action exists. 
relationship between administrative failure and the local political community. In addition to the argument that the fourteentl amendment sloould prohibit imjuries from administrative failure, this Part argues that administrative failure may not be amenable to correction through local democratic processes. Therefore, the federal courts could enhance democracy and protect against injuries by forcing local governments to correct administrative failures.

There are several steps to the argument that civil rights litigation provides an appropriate vehicle for correcting local administrative failure. First, a discussion of the types of administrative failure and their causes provides a background to the problem. Second, suggestions are made concerning the appropriate judicial response to such failures. The primary suggestion liere is that the local political system might not provide adequate correction for reasons unrelated to the desires of the electorate. Finally, a few questions concerning the section 1983 remedy are addressed, including the potential problems with relying on state courts for remedies.

\section{A. Forms of Administrative Failure}

To develop the argument that local administrative failure should be remedied through civil rights actions, we must first understand the types and causes of administrative failure; this, in turn, requires an understanding of what constitutes proper administration. That is, we need to know the legislative intent underlying the authorizing act and perliaps also the intent behind the regulations in order to create a standard by which to measure whether an agency succeeds or fails.

Administrative failure manifests itself im many forms and can result in either overregulation or underregulation. Altliough DeShaney and the general situation I consider involves failure to regulate adequately, in many situations an agency could overregulate. ${ }^{88}$ Overregulation could be caused by agents who desire more power or more security im their position or by the influence of an interest group that will trade something of value for benefits of more regulation. Although the analysis that follows focuses primarily on underregulation, it is in no way intended to dispute the potential for failure of the opposite form.

88. For example, in the Benzene Case, if the Supreme Court were correct that Congress had intended to address only significant health risks, and if there were no good reason to address less serious risks, then the Occupational Safety and Health Administration's (OSHA) regulation limiting benzene levels in the workplace environment to one part per million was an example of overregulation. See Industrial Union Dep't, AFL-CIO v. American Petroleum Inst., 448 U.S. 607 (1980) (The Benzene Case). 
Even though certain forms of agency failure, such as graft and waste, may be easy to spot, it is far more difficult to decide whether other forms of conduct amount to misconduct. The difficulty in deciding whether an agency is mecting its inandate is best illustrated by the controversial litigation often spawned by agency action. ${ }^{89}$ Each term the Supreme Court's docket contains numerous cases in which parties argue that a federal agency is violating its statutory inandate. $\%$ With different interests competing for agency attention, one person's administrative failure may be another's success. 91

Because there are so many variables involved in determining whether administrative failure exists, it is impossible to define it with any precisiou. ${ }^{92}$ However, soine rough generalizations concerning administrative failure will aid in the inquiry. In any large organization, the incentives of the various actors may differ, and momitoring costs may make it either difficult or impossible for the legislature, executive or agency

89. See, e.g., Citizens to Preserve Overton Park, Inc. v. Volpe, 401 U.S. 402, 413 (1971) (agency action must be set aside if it is capricious); The Benzene Case, 448 U.S. at 607 (decision exploring the rationale of an agency determination to reduce the permissible exposure limits to carcinogens).

90. For example, during the October $1989 \mathrm{Term}$, the Court decided several cases regarding the propriety of agency action, mcluding Sullivan v. Zebley, 110 S. Ct. 885 (1990) (invalidating Social Security regulations requiring child claimant to match disability with a listed disability as inconsistent with Social Security Act's "comparable severity" language); Sullivan v. Everhart, 110 S. Ct. 960 (1990) (upholding netting regulations as consistent with Social Security Act); Dole v. United Steelworkers of America, 110 S. Ct. 929 (1990) (holding that the Paperwork Reduction Act does not grant the Office of Management and Budget authority to review agency rules inandating disclosure to third parties). The difficulty of defining bureaucratic failure is further illustrated by the scholarly commentary. For example, Morris Fiorina defines bureaucratic failure as occurring when "an ideologically mixed bag of observers consensually reject or condemn a bureaucratic rule, practice, decision, or other behavior when the latter is described in the abstract." Morris Fiorina, Flagellating the Federal Bureaucracy, in The Polmical Economy, supra note 50, at 224, 227. The most immediate weakness in Fiorina's definition is that it does not assume that the same group of observers agreed with the agency's statutory mandate.

91. Fiorina raises the example of a program that might operate contrary to the general intent of the legislature, but consistent with the desires of the small number of legislators with a strong interest in the program. See Fiorina, supra uotc 90 , at 228. Similarly, a program that could operate in the general public interest might not do so because of capture by the regulated industry. Lobbying generally is likely to be done by a sinall group of intensely interested parties; that lobbying might be, as Downs argues, biased toward production activities (the producing industry) and not consumption (consumers). See Downs, supra note 50, at 23.

92. Both Logan and DeShaney appear to present relatively clear cases of adininistrative failure: The agency in Logan failed to provide even a hearing to determine whether discrimination had occurred, and the agency in DeShaney failed to prevent child abuse despite glaring evidence of abuse. But even in thesc cases the existence of failure was not clear to many of the judges that heard the cases. In Logan, the Supreme Court of Illinois lield unanimously that the state legislature intended that mandatory proceedings should halt under the circumstances. Zimmernnan Brush $\mathrm{Co}$. v. Fair Employinent Practices Comm'n, 82 III. 2d 99, 411 N.E.2d 277 (1980), rev'd sub nom. Logan v. Zimmerman Brush Co., 455 U.S. 422 (1982). In DeShaney, the Supreme Court of the Umited States hinted that the social worker may lave made the right decision by avoiding a violation of the sanctity of the DeShaney family. DeShaney, 489 U.S. at 203. 
head to ensure proper conduct. ${ }^{93}$ As noted above, graft is the easiest form of administrative failure to identify. Slightly more difficult to identify is waste, im the form of resources that are used either for the personal benefit of the agent or for no good reason at all. Altliough neither the opinions nor the record in either case indicate why the administrative failure occurred, DeShaney and Logan appear to fall into another category of administrative failure-a failure due to laziness, incoinpetence, or overwork.94 In Logan, the Court considered it irrelevant whether the agent failed to convene a timely hearing purposely or inadvertently. In DeShaney, the Court gives no explanation for wliy the social worker took no further steps even with the clear evidence of continued abuse and the difficulty the social workers experienced in trying to see Joshua. It inay be that the administrators were lazy, thus trying to minimize their workloads at taxpayer expense, in a fashion contrary to legislative intent. It may be that they were incompetent or overworked, and in spite of their good faith efforts, the social workers could not fulfill their statutory mandates. Further, it may be difficult to decide whether the failure is consistent with or contrary to legislative intent: Although stated regulatory goals were not inet, funding decisious by the same legislature might have made it impossible to hire qualified administrators or to hire enough administrators to function coinpetently.

Otlier forms of regulatory failure relate more closely to the traditional questions in administrative law. Administrators might, for a variety of reasons, develop regulatory goals different froin those set forth by the legislature. Legislative oversight by a narrow group of interested legislators might lead agencies away froin the general legislative intent.95 Agencies imight be influenced by the lobbying of a narrow group of interested parties whose views do not represent the electorate or even the enacting legislature.96 And agencies might develop their own substantive

93. See Fiorina, supra note 90 , at 230 . At the federal level, where such things have been studied, the lack of effective oversight has been decried as a major failure regarding the administrative state. See Mathew McCubbins \& Thomas Schwartz, Congressional Oversight Overlooked: Police Patrols versus Fire Alarms, 28 AM. J. PoL. ScI. 165, 165-66, 176 (1984). The authors distinguish between "police patrol" oversight, in which the legislature constantly monitors administrative activity and "fire alarm" oversight, in which the legislature waits for interested parties to sound alarms. The authors conclude that the latter inethod is most often employed by Congress because it works better and is less expensive.

94. Social service agencies are notoriously overworked. See Martha Brannigan, In a State Aid Agency, Overwhelmed Staffers Fight a Losing Battle, Wall St. J., Aug. 15, 1988, § 1, at 1, col. 1.

95. See infra notes $106-07$ and acconpanying text.

96. See George Stigler, The Theory of Economic Regulation, 2 BELL J. OF ECON. \& MGMT. SCI. 3 (1971). 
views or be influenced by executive branch views contrary to the legislative intent. 97

The pathologies of regulatory failure reveal why judicial intervention might be part of the cure. Sone argue that the inost appropriate conditions for judicial review occur when political failures inake it unlikely that the results of the political process reflect the will of the electorate. 98 Under these conditions, denocratic processes will be of no avail in correcting the failure. In such situations, judicial supervision can increase accountability, and therefore the denocratic control of governinent with regard to administrative activity.

Take first the possibility that the agents are overworked because the agency has inadequate funds to carry out its mission. As revealed by subsequent hitigation, ${ }^{99}$ this inay have occurred in Logan, and a heavy caseload could easily have contributed to the failure in DeShaney. Information about funding levels may not coine across to the electorate clearly enough to influence elections. ${ }^{100}$ Moreover, incumbents possess an ad-

97. The controversy over Executive Order 12,291, promulgated in 1981 by President Reagan, illustrates the problems that presidential involvement with regulation presents. See 3 C.F.R. 127 (1982). The Executive Order gave the Office of Management and Budget (OMB) the authority to review regulations proposed by various agencies to ensure that the regulations took costs and benefits into account. The President's authority to command that cost-benefit analysis be part of the regulatory process and to require agencies to submit regulations to $\mathrm{OMB}$ for review was controversial froin the start. See Erik Olson, The Quiet Shift of Power: Office of Management \& Budget Supervision of Environmental Protection Agency Rulemaking under Executive Order 12,291, 4 VA. J. NAT. RESOURCES L. 1 (1984). Olson's article provides useful citatious on the OMB review controversy. See id. at 3 n.3; see also Symposium on Administrative Law "The Uneasy Constitutional Status of the Administrative Agencies," 36 AM. U.L. REV. 277 (1987). Another problem with executive oversight is that a new President may want to change enforcement of a preexisting statute. This problem came to a head in Motor Vehicle Mfrs. Ass'n v. State Farm Mut. Auto. Ins. Co., 463 U.S. 29 (1983) (Secretary of Transportation, in rescinding rule requiring passive restraints in passenger cars, failed to adequately justify her decision).

98. See United States v. Carolene Prods. Co., 304 U.S. 144, 152 n.4 (1938); JoHn HART ELY, DEMOCRACY AND DisTrust 183 (1980).

99. See Bennett v. Tucker, 634 F. Supp 355 (N.D. Ill. 1986), rev'd, 827 F.2d 63 (7th Cir. 1987) (class action alleging that 2500 people lost their employment discrimination claims because of administrative processing failure).

100. A comparable argument has been inade in support of the Court's distinction between procedure and substance in due process cases. In those cases, the Court looks only to the substantive features of a statute to determine whether due process requires some sort of a hearing; it ignores statutory sections stating that little or no process attaches. Stewart and Sunstem state that one justification for this, albeit one that they find weak, is that the electorate may not know about the procedural limitations (which Stewart and Sunstein call "surreptitious sabotage") on a substantive program they may favor. Thus, officials might tout a statutory entitlement that, in fact, provides little real gain. See Stewart \& Sunstein, supra note 26, at 1258-59. I disagrec with their assessment of the weakness of this argument. They think that separation of powers principles stand against courts imposing their own ideas of politieal responsibility. But the separation of powers principles are largely judge-made, and the courts unight not be as sympathetic to sucls arguments when political accountability is at stake. To ine, the positive role courts can play here in improving the functioning 
vantage because they have greater access to information with regard to the operation of agencies. ${ }^{101}$ Incumbents may use the substantive contours of a regulatory program for pohtical advantage: For example, they may take credit for a popular program such as an employment discrimination law or child welfare statute. But incumbents are unlikely to announce that the agency is not fulfilling its function due to madequate resources, and they may attempt to shift the blame for any failures to others, such as the administrators or political opponents. ${ }^{102}$

Politicians persuade members of the political commumity to support them, in part, by slowing that their political behefs and histories place them within the ideology and interests of the commumity. ${ }^{103}$ Insofar as politicians can use the electorate's lack of information to their advantage, the results of the political system are distorted. Further, administrative failures may be so low on the pohtical agenda that they will not even be addressed in the electoral process. ${ }^{104}$ If the beneficiaries of the regulation tend to be weak and outside the political process, then the likelihood that the political process will provide a renedy for the failure is reduced even more.

The agent or agency pursumg goals that are at odds with the legislature's intent amounts to another source of administrative failure-a failure of the political system. If the legislation itself reflects the will of the pohitical community (an admittedly controversial assumption), ${ }^{105}$ then any deviation from the imtent of the legislature should be condemned as undemocratic. Deviation from legislative goals can occur in a number of

of the political system and helping victims such as Joshua outweighs any interests elected officials have in preserving the weaknesses in accountability that have been identified.

101. See Downs, supra note 50, at 141. In general, imperfect information allows incumbents to maximize credit-claiming and minimize responsibility for failures. See Morris Fiorina, Legislative Choice or Regulatory Forms: Legal Process or Administrative Process?, 39 PUB. CHOICE 33, 48-49 (1982). The news about inadequate funding may be suppressed while the good points of the program are trumpeted.

Sounetimes the disjunction between policy and funding will not go unnoticed. For example, President George Bush recently spoke out strongly in favor of care for victims of Acquired Immune Deficiency Syndrone (AIDS). His critics pointed out that "Mr. Bush had removed froun his budget crucial money for AIDS drugs and all of the inoney for demonstration projects on hoine and community care." Phillip Hilts, Bush, in First Address on AIDS, Backs a Bill to Protect Its Victims, N. Y. Times, Mar. 30, 1990, at A1, col. 3.

102. Morris Fiorina has argued that the idea behind setting up an administrative agency with discretion might partly be to allow lawmakers to shift blame for failures to the agency. See Fiorina, supra note 90 , at $46-54$.

103. See Downs, supra note 50, at 16-17.

104. See Note, supra note 67 , at 639 . The note as a whole makes a well-documented argument in favor of judicial review, under the Administrative Procedure Act, of agency inaction in the form of failure to implement statutes. The note rejects justiciability limits that have been raised as arguments against such review. See id. at 645-61.

105. See generally Theodore Lowi, THE END of Liberalism 57-61 (2d ed. 1979). 
fashions. Oversight activities are likely to be dominated by a small group of intensely interested lawmakers whose interests inay or may not reflect the views that led to the passage of the legislation. ${ }^{106}$ Lobbying by regulated parties inay overwhelm the voices of those who lack a great individual stake in the regulation, and collective action problems may prevent a strong response. ${ }^{107}$ Additionally, unelected agents are shielded from direct political scrutiny. Thus, given the difficulty of effective oversight, ${ }^{108}$ agency actions may not be brought into line with legislatively stated goals. Again, information is unlikely to be widely disseminated because those with the information may not have a strong incentive to make it public.

One also could attribute agency failure to a misalignment of the incentives of agents with agency goals. ${ }^{109}$ Because of the realities of government bureaucracies, ${ }^{110}$ government agencies cannot easily inomitor individual agent's behavior for fidelity to regulatory goals. Agents may simply shirk their responsibilities and minimize the ainount of work they do. Although inany agents are drawn to their jobs by a commitment to the work of the agency, this is not universally true; and even the most dedicated agents may be adversely affected by the lack of mcentives to perform well. My general intunition is that as the local political cominumity becoines less integrated, and the bureaucrat becomes more alienated froin the population that depends on the agency, the lack of direct imcentives to perform becoines an increasing problem. ${ }^{111}$ If the social worker in DeShaney and the hearing officer in Logan had no significant personal incentives to perform properly, one should not be surprised that they failed.

106. See McCubbins \& Schwartz, supra note 93 , at 172, 174-75. Oversight also may be ineffective because legislators may lack time to address every administrative failing, especially if the issue is not one of general political interest. See Note, supra note 67, at 639-40. The note argues these same types of factors also may explain why the President cannot effectively oversee agency maction. See id. at $641-42$.

107. See Downs, supra note 50, at 23-24. Downs argues that economic factors make lobbying and "government submission to the demands of lobbyists" perfectly rational because lobbyists control resources that politicians need for continued political support and reelection.

108. In fact, civil rights suits can be characterized as a form of "fire alarm" oversight. See supra note 93 and accompanying text.

109. See Fiorina, supra note 90 , at 227.

110. Government agencies operate under political pressures whiels may make it impossible to optimize size and monitoring capabilities the way that private firms might be able to do. See Ronald Coase, The Nature of the Firm, 4 ECoNomca (n.s.) 386, 394-95 (1937) (arguing that firms grow only to the point that the gains from growth outweigh the losses from imability to monitor perfonnance of employees).

111. More specifically, my inturition is that as the local community becounes larger and more diverse-and a professional, pohtical, and bureaucratic class develops-the likelihood that government policy will mirror the desire of the community decreases. For discussions of this sort of problem on the national level, see T. LowI, supra note 105, at 212-24; Downs, supra note 50, at 148-49. 
In all of these situations, judicial scrutiny of the administrative failure will increase the ability of the local political community to control government action. The operative assuniption here is that the pohtical community is less likely to receive and appreciate information about administrative failure than information about the substantive requirements of state law. Judicial scrutiny would prevent incumbents from trumpeting a program on tlie one hand and not funding it on the other because courts would be able to grant a reinedy to those injured by the failure to fulfill regulatory goals. This remedy is whit the Supreme Court's Logan decision imposed upon Illinois. Pohiticians, thus, could not take advantage of the commumity's lack of information because courts would intervene and remedy tliose failures that cause injuries to protected interests. ${ }^{112}$

In eases that involve administrative failures in which the agencies purposely fail to carry out statutory goals, judicial scrutiny could bring administrative action in line with legislative goals. ${ }^{113}$ Lawsuits can function like fire alarms, alerting the political community to the existence of administrative failure and creating incentives through damage awards (and injunctive rehef) for agencies to conform their conduct to the law. ${ }^{114}$ Further, the use of court actions as oversight would enhance control over agencies by the elected officials who are inore directly accountable to the electorate. Agents would have to analyze the costs of potential damages that they miglit incur for their failure to act in consonance witli regulatory goals. ${ }^{115}$

112. The disjunction between funding and substance raises the difficult issue of federal court power to order expenditure of funds to bring local programs into compliance with the Constitution. Although the Court has ordered states to spend money to comply with the Constitution, see Milliken v. Bradley, 433 U.S. $267,288-90$ (1977), and has rejected lack of funds as a defense to a constitutional claim, see Bounds v. Smith, 430 U.S. 817, 824-26 (1977), federal court power to order appropriation of funds sufficient to operate a local agency effectively is uncertain. My analysis, however, favors judicial exercise of such power. See Missouri v. Jenkins, 110 S. Ct. 1651 (1990) (federal court may require a local government to levy taxes in excess of state statutory limits so as to fund a school desegregation plan); cf. Spallone v. United States, 110 S. Ct. 625, 631, 634 (1990) (contempt orders against city council members for failing to enact affordable housing ordinance held improper; district court should have proceeded first against city alone; certiorari on propriety of order requiring city to enact affordable housing ordinance was denied).

113. See Stewart \& Sunstein, supra note 26 , at $1282-83$ (judicial intervention to require mitiation of regulation may increase faithfulness to statutory directives).

114. See id. at 1278 (private rights to initiate suit can fill the gap between electoral responsibility and bureaucratic regulation). Stewart and Sunstein do not address, in their discussion of private rights of initiation, the possibility of damages directly against the agency or agent, but their analysis is largely applicable to both issues so long as both types of action have the same effect on administrative action. They do include, in their discussion of private rights of action, the possibility of damage actions against administrators, but they do not explore this issue in detail. See id. at 1289-1315.

115. An unstated assumption here is that judges have an ineentive to use their power of review to enforce legislative goals and not their own goals. This assumption may not be accurate, and this 
Some regulatory failure can be corrected through the political process. Large-scale failure that affects interests of those who possess the resources and ability to lobby is unproblematic; this group may respond loudly and persuasively when agency action or inaction affects their interests. In cases like Logan and DeShaney, however, which involve relatively weak and insular victims, a lobbying effort is less likely to be sufficient to move administrators to remedy the failure. Thus, one justifcation for finding a due process violation when state regulation fails and mjury to protected imterests occurs is that defects in the political process make it unlikely that the local political community can act to correct the failures. By viewing regulatory programs as promises to the beneficiaries, the courts can force the government to guarantee their promises and thus correct for administrative failure.

\section{B. The Civil Rights Connection}

Once we establish a governmental duty to act, the final question is whether a section 1983 civil rights suit is the appropriate avenue to enforce this duty. Section 1983 is the primary device by which parties bring their constitutional claims against state officials into federal court. Because section 1983 is part of a statute denommated "An Act to Enforce the Fourteenth Amendinent" many of the arguments for a section 1983 remedy are the same as the due process arguments and do not need repeating. In this Section, I highlight a few of the reasons why the civil rights remedy is appropriate to combat unconstitutional failures to intervene against private misconduct-especially when that misconduct injures a powerless member of society.

A major theme that the Court emphasizes with regard to the appropriate scope of seetion 1983 is the statute's role in placing the federal courts between the citizen and the state im order to protect the citizen from injuries. ${ }^{116}$ The mjuries caused by state official conduct that courts recognize as compensable section 1983 injuries-bodily injury and other common law mjuries-are the same sort of injuries that occurred in DeShaney. ${ }^{117}$ Further, the language, legislative history, and historical

possibility presents a serious problem for any theory that depends on judicial action. I intend to address the question of judicial incentives in a future article. See Jack Beermann, Interest Group Politics and Judicial Behavior: Macey's Public Choice (unpublished manuscript 1990) (available from author).

116. See, eg., Patsy v. Board of Regents, 457 U.S. 492, 503-05 (1982) (purpose of section 1983 to protect federal civil rights by interposing federal courts betwcen the individual and the state); Monroe v. Pape, 365 U.S. 167, 180-83 (1961) (section 1983 enacted to prevent state agencies from denying citizens the rights guaranteed by the fourteenth amendment).

117. See Carey v. Piphus, 457 U.S. 247 (1978). For a close parallel to DeShaney, see Smith v. Wade, 461 U.S. 30 (1983) (prison guard hable for punitive damages under section 1983 for recklessly 
context of section 1983 favor an application of the statute that remedies the "states' failure to protect the individual's constitutional rights."118 Professor Soifer also lias argued that the post-Civil War amendments were designed to impose upon states-sovereignty interests notwithstanding-duties to protect people from private violence in some situations. ${ }^{119}$ This history may not be very specific, but the test for propriety in constitutional law is not whether the Framers would have given the same answer as the Court. ${ }^{120}$ Rather, history provides guidance, support, and an answer to critics who demand historical footing for constitutional development. The potential for mjury due to government failure to act is as great or greater than at the time when section 1983 was enacted. Therefore, the section 1983 remedy should be available in situations such as DeShaney.

Basic premises underlying an expansive view of section 1983 militate in favor of its application to remedy failures to protect. Section 1983 and its jurisdictional counterpart ${ }^{121}$ grant a federal remedy to victims of state violations of federal rights in order to allow the plaimtiff to clioose a forum that is less likely to be biased in favor of state interests and against federal riglits. For a variety of reasons, the local courts may not provide sufficient redress for the ijjuries in situations in which local government fails to act. ${ }^{122}$ State law often discriminates against claimants who seek damages against goverument officials for tortious conduct. For example, although Wisconsin tort law liberally imposes hability for public ${ }^{123}$ and private $^{124}$ torts im situations sucl as DeShaney, it also sets limits on dam-

disregarding the federally protected civil rights of an inmate by placing him, while under protective custody, in a cell with other inmates with a proclivity for fighting).

118. E. Keynes, supra note 26, at app. 23.

119. See Soifer, supra note 26 , at $686-87,700$.

120. For example, with respect to the fourteenth amendinent the Court has ignored the specific views of the Framers of the amendinent. See, e.g., Brown v. Board of Educ., 349 U.S. 294 (1955).

121. 28 U.S.C. \$ 1343 (1988).

122. Another potential problem with a section 1983 remedy here is immunity under the eleventh amendment. While local government units have not been granted eleventh amendment immunity, see Monell v. Department of Social Servs., 436 U.S. 658, 690-95 \& n.55 (1978), states and state officials enjoy broad immunity against damage actions in federal court. See Edelman v. Jordan, 415 U.S. 651 (1974). The debate about the proper scope of the eleventh amendment and sovereign iminunity is ongoing, and I do not wish to enter it liere except to state that I agree with the critics who argne that the eleventh amendment should not bar federal claims. See Beermann, Official Torts, supra note 7, at 336-40 (discussing and citing literature and recent cases concerning eleventh amendment and state sovereign immunity).

123. See Wood v. Milin, 134 Wis. $2 d$ 279, 397 N.W.2d 479 (1986) (holding building inspector liable for failing to inspect building that later collapsed).

124. See Schuster v. Altenberg, 144 Wis. $2 d$ 223, 424 N.W.2d 159 (1988). In Schuster, the Wisconsin Supreme Court lield that a psychiatrist could be lield liable for failing to warn a patient's family about the patient's potentially dangerous condition. The court rejected the argument that no duty to warn existed when no identifiable victim existed. It held that the general principles of Wis- 
ages recoverable against government that frequently are too low to provide adequate compensation. ${ }^{125}$ The lack of adequate damage remedies for state tort victims should be a cause for federal concern. ${ }^{126}$

The common-law-like section 1983 remedy ${ }^{127}$ also can help create incentives for agents and agencies to perform their jobs properly. Section 1983 helps both to ensure that state law conforms to the Umited States Constitution and to kcep state officials under control when their conduct violates both state and federal law. As discussed above, ${ }^{128}$ the incentives that prompt state officials to act may not be consistent with state regulatory goals or federal constitutional principles. When section 1983 remedies tend to encourage comphance with those norms, the remedies accoinplish their purpose.

Of course, the incentives may go too far. The limits on the state's duty to intervene, as imposed under section 1983, are not altogether clear. As the duty to intervene becomes stronger, the objections to intervention based on local political autonouny becoine greater. For example,

consin tort law permit a finding of negligence liability whenever an "act or omission to act could cause harm to someone" Id. at 232,424 N.W.2d at 163. The limit on such liability is apparently foreseeability. The court explicitly recognized that its tort doctrines might create "an affirmative duty to act." Id. at 238, 424 N.W.2d at 165. But see Winslow v. Brown, 125 Wis. $2 \mathrm{~d} 327,371$ N.W.2d 417 (Wis. Ct. App. 1985) (passengers in automobile had no duty to prevent driver from driving on bicycle path even though driver's actions were clearly dangerous to users of path).

125. See supra note 80.

126. I have elsewhere developed a lengthy argument that government failure to provide compensation for its torts should be held unconstitutional. See Beermann, Official Torts, supra note 7. The main thrust of the argument is that government should not be allowed to externalize randomly the costs of its operation, and that the best measure of the costs of the operation of government is the rules that govern private liability. Therefore, government should be liable whenever a private party would be liable.

127. By the use of the term "common-law-like" I refer to two distinct attributes of the section 1983 remedy. First, the Court often refers to section 1983 as a species of tort liability. See, e.g., Carey v. Piphus, 435 U.S. 247, 253 (1978) (Court observes that rules developed in tort law defining damages and recovery provide the foundation for inquiries under section 1983); Smith v. Wade, 461 U.S. 30, 34 (1983) (Court noted that section 1983 had its origins in section 1 of the Civil Rights Act of 1871, ch. 22, 17 Stat. 13, which sought to create a form of tort liability for federally protected rights. Utilizing this information the Court looked to the common law of torts to arrive at the purposes and policies of section 1983.). Recently, this reference has signaled the Court's unwillingness to expand section 1983 damages beyond injuries that were compensable at common law. See Memphis Community School Dist. v. Stachura, 477 U.S. 299 (1986); see also Sheldon Nahmod, Section 1983 Discourse: The Move from Constitution to Tort, 77 GEo. L.J. 1719, 1720 (1989) (arguing that the Supreme Court's "tort" references in section 1983 cases are ineant to "make it less protective of fourteenth amendinent riglits"). Second, because of its general terms, the Court's reasoning about the proper scope of the section 1983 remedy resembles common law reasoning in the way that policy, principle, and statutory authority are taken into account. See RiCHARD POSNER, ThE Federal COURTS: CRISIS AND REForM 300-01 (1985); William Eskridge, Dynamic Statutory Interpretation, 135 U. PA. L. REv. 1479 (1987). See generally Beermann, Section 1983, supra note 38 , at 76-84.

128. See supra notes $96-115$ and accompanying text. 
one powerful argument against an enforceable claim against local government to minimum food and shelter is that the local political community should be free to allocate resources, because the local community can better comprehend local needs. But the nore specific the duty beconies, the nore reliance people may place on the promises contained in state regulatory programs. If federal courts were to recognize this reliance interest, then states would have an incentive to give up programs, rather than face the possibility of liability. Whether this abandonment would materialize depends, at least in part, on the strengtli of the pohtical community's commitment to provide the services.

In sum, once the forms and causes of administrative failure are understood, the case for judicial intervention beconies much stronger. People have grown to depend on administrative action, and the consequences of failure to act are often just as serious as errant action. Further, judicial intervention can enhance the political systenı's accountability for the conduct of administrative officials.

\section{CONCLUSION}

The purpose of this Essay has been to explore the normative underpinnings of a constitutional theory that assigns government, in soine circumstances, the duty to protect members of society fron private violence. The constitutional obligation of government to protect the weak in society should be recognized regardless of government's previous promises or actions. This argument is constructed from the current structure of our society and from the moral landscape of increased social attention to the needs of the powerless. Joshua DeSlianey and other powerless victims of private violence slould be the beneficiaries of the fourtecntli amendment; victims should be able to hold the state responsible for failing to protect then. State failure to act to protect these people-especially when state agents know of the plight of the victimsmeets any definition of "outrageousness" formulated by the Supreme Court as a due process test.

The existence of state agencies designed to attack private misconduct strengthens the argument for intervention. The state nuakes statutory promises to protect the weak; by failing to treat its tort victims the same as victims of torts inflicted by non-governmental actors, the state violates the guarantees of due process. Because of the victim's weakness, and because state agencies nuay have displaced other sources of relief, the victims often have nowliere else to seek aid. Thus, states should be forced to live up to their promises of help against private misconduct.

Furtlier, judicial intervention that remedies state failures to actfailures that contribute to liarm to protected interests-can help our 
political community realize three separate sets of ideals. First, judicial intervention is consistent with the inoral commitment to protection froin private misconduct and the dangers of life-a commitment that explains inuch of the activity of contemporary government. Second, by keeping local administrators accountable to the electorate, the ideals of democracy will be advanced. Finally, broad application of the fourteenth amendment and the section 1983 remedy can help ensure state government and official accountability.

There are two related problems witl imposing positive duties on government: the lack of boundaries and the displacement of local choices. On the first point, I do not see more uncertainty here than in many nascent areas of law, and there is nothing inherent in the recognition of positive constitutional rights that inakes development of doctrinal limits more difficult than usual. Courts, operating on a case-by-case basis, should be able to identify compelling cases for judicial intervention. If after a period of concerted effort, this approach proves unsuccessful, rcconsideration imght be in order. ${ }^{129}$ On the second point, I am not convinced that there is a democratically chosen position that would be frustrated by judicial intervention. Often, injuries occur because government officials neglect their legal duties, or work to subvert rather than advancc legislative purposes. Judicial intervention can increase, rather than degrade, political control and accountability.

In sun, the rhetoric and social vision of the world of negative rights is out of place in today's society. It makes little sense to decry positive rights in the welfare state, especially once the pervasive role of government in shaping society is recognized. It would be inucli more productive if the discussion were redirected toward exploring the contours of society's responsibilities toward the unfortunate and the ways in which social clioices create the conditions for administrative failure and increase the consequences of such failure. Even if the Court, pursuing this line of reasoning, were to come out against a duty to protect, this would be an advance over the current jurisprudence-a jurisprudence that refuses to acknowledge the role of government within the structure of our society.

129. In the past, the Supreme Court has proved willing to change directions when an approach has proved unsuccessful. For example, in Garcia v. San Antonio Metro. Transit Auth., 469 U.S. 528 (1985), the Court overruled the amorphous constitutional standard set forth in National League of Cities v. Usery, 426 U.S. 833 (1976). In Garcia, the Court recognized that the National League of Cities standard was "unsound in principle and unworkable in practice." Garcia, 469 U.S. at 546. 